\title{
BITTEN WOUNDS OF THE MAXILLOFACIAL AREA IN CHILDREN
}

DOI: 10.36740/WLek202006105

\author{
Pavlo I. Tkachenko, Serhii O. Bilokon, Olha B. Dolenko, Nataliia M. Korotych, Yuliia V. Popelo, Nataliia P. Bilokon \\ UKRAINIAN MEDICAL STOMATOLOGICAL ACADEMY, POLTAVA, UKRAINE
}

\begin{abstract}
The aim of the work is to determine the frequency, structure, features of clinical manifestations and treatment of bitten wounds of the face and neck in children of Poltava region. Materials and methods: It has been analyzed 91 histories of disease of thematic patients undergone treatment at the Surgical Department of Pediatric town clinical hospital of Poltava.

Results: In the structure of traumatic injuries of maxillofacial area in children $5.3 \%$ were patients with bitten wounds of the face and neck. Among the injured were children of the age $7-12$ years old (30.2\%). In $74.7 \%$ of cases, the bites were complicated by acute inflammatory processes. Urban residents accounted for $71.8 \%$ of the total number of cases, while rural residents accounted for $28.2 \%$. Boys were injured by $53.6 \%$ and girls by $46.4 \%$. Sharps (74.5\%), punctures (19.3\%) and lacerations (6.2\%) differed in form. The comprehensive treatment of patients with bitten maxillofacial area wounds was carried out according to the protocol of care.

Conclusions: The clinical picture and severity of bitten wounds of maxillofacial area in children have individual features, which are largely due to topographic and anatomical localization of injuries.

The choice of the optimal variant of primary surgical treatment of wounds and the amount of surgery should be determined individually depending on the severity of the injury, the time of injury. Special attention should be paid to normalization of psycho-emotional state of patients and prevention of scar formation.
\end{abstract}

KEY WORDS: children, bitten wounds, maxillofacial area, treatment

Wiad Lek. 2020;73(6):1108-1113

\section{INTRODUCTION}

It is known that the age-specific features of the anatomical structure of the face cause the versatility and sometimes inconsistency of the general appearance of post-traumatic wound defects of severity and the nature of the injury itself. According to statistics, the most frequent causes of injuries of the maxillofacial area (MFA) in children are road accidents $(41.3 \%)$, domestic (39.6\%) and sport (13\%) injuries and other factors $(6,1 \%)[1,2,3]$. In $65 \%$ of cases, children between the ages of 6 and 14 are injured, and boys are twice as likely as girls. About $35 \%$ are $4-5$-year-old patients treated for soft tissue injury (ST), with injuries inflicted by animals predominant in the structure of injuries $[4,5]$. In general, the frequency of bitten wounds among all traumatic injuries is $7-12 \%$, and in the area of head and neck - up to $34.5 \%$ with a steady tendency to increase their number recently $[6,7]$.

Researchers say that dogs, cats, rodents, insects, or humans are the most affected by bites, moreover (up to $84 \%$ ) injuries caused most often with dogs, most of them (up to $67 \%)$ being vaccinated, and cats $(15.4 \%)[4,8,9]$.

The likelihood of damage to facial muscles with their multifaceted interconnection and cause and effect disorders, especially neurological ones, requires a well-tailored individual approach to the treatment and rehabilitation of each individual child [8].

Research of the staff of our department has revealed disorders of psycho-emotional state and behavioral reactions in children with injuries of ST, which is why traumatization of the psyche was the most frequent: even when visual assessment of their appearance, such patients had negative reactions, which were followed during communication with each other on all stages of comprehensive medical care. This necessitated the need to pay considerable attention to the outreach work not only with the child but also with her relatives. In addition, special attention should be paid to improving their quality of life in the postoperative period by determining the ways of sedation in this category of patients and the need for correction of changes in the oral fluid [10].

\section{THE AIM}

The aim of the work is to determine the frequency, structure, features of clinical manifestations and treatment of bitten wounds of the face and neck in children of Poltava region.

\section{MATERIALS AND METHODS}

The staff of the Department of Pediatric Surgical Dentistry thoroughly analyzed the content of 91 histories of disease of thematic patients who were treated at the surgical department of Town Polyclinic of Pediatric Dentistry of Poltava for an 8-year period, determining the frequency and structure of bitten wounds of the head, face and neck. Clini- 
cal symptomatology of the course of the wound process and features of treatment of the bitten wounds are determined by direct observation of the respective patients. General clinical, additional, and sometimes special examination methods were used to determined the clinical diagnosis.

Given that there is no detailed classification of bitten wounds of MFA in children, in clinical practice we used a general surgical nomenclature, separately distinguishing any bites caused by non-native predators, considering them, like other researchers $[4,6]$, quite difficult.

In some cases, they used a rather interesting, in our opinion, the clinical classification of injuries of MFA, caused by dogs, in children, proposed by V.V. Liubym (2004), where the author takes into account the degree of injuries and their number, the presence of facial injuries, the occurrence of clinical symptoms of infection $[8,11]$.

The collection of anamnesis of the disease included the determination of the species of the animal, its location and time and circumstances of the injury, the nature of the previous measures. In general, the treatment of patients was carried out according to the protocol of providing medical care to patients with bitten wounds, but the choice of the optimal variant for primary surgical treatment of wounds and the amount of surgical intervention depended on the severity of the injury, taking into account the individual topographic-anatomical localization of the injury itself $[4,7,8,8]$.

\section{RESULTS AND DISCUSSION}

In the table 1 it is showed the average distribution of the bitten wounds of the MFA according to localization, which in some way coincides with the data given in the literature concerning the occurrence of these types of traumatic injuries in other regions of Ukraine $[4,5,6]$. They accounted for $5.3 \%$ of the total number of patients with various traumatic injuries of MFA. The largest part of the injuries was in the anatomical areas, which were prominent: the lips, cheeks, cheeks, nose and multiple wounds have a small proportion (Table I).

Of the victims, urban residents accounted for $71.8 \%$ of the total population, while rural residents accounted for $28.2 \%$. Boys were injured by $53.6 \%$ and girls by $46.4 \%$ (Table II).

The careful collection of medical history allowed us to determine that a large percentage of bitten wounds in the nursery, preschool and young age groups are due mainly to improper conditions of animals, carelessness and irresponsibility of parents, features of child psychology (curiosity, lack of insanity) little life experience and inability to reasonably understand the possible consequences. Instead, in the older age group, injuries are primarily caused by adolescents' challenging behavior, which, in the absence of animal communication skills, predominantly provoked the latter's response and resulted in bites. This is the opinion of other researchers, too $[1,2,3,4,6,8]$.

In our observations, animal bites were most often recorded in the summer (68 cases $-74.7 \%$ ). Depending on the type and degree of physical contact of the child with the animal, there were salivation of the skin on the area of the saddles, salivation of the damaged skin with the intact mucous membrane, light bites (single, shallow, combined with bites of the limbs, trunk,) single bites and scratches of the brush (except fingers), salinization of damaged mucous membranes, severe bites (any bites of the head, face, neck, fingers, wide bites).

Sharps $(74.5 \%)$, punctures (19.3\%), and lacerations wounds (6.2\%) were distinguished by their shape, and the torn ones, irregularly shaped, were usually accompanied by significant distortion of the damaged tissues and bleeding profusely, most often formed after a sharp fang of animals, they had a deep wound canal with a small inlet.

In all cases, there was a pronounced glow of the edges of the wound, especially in the area of the lips, the naso-labial folds and cheeks, creating the appearance of great loss of tissues, and with damage to the circular muscle there was no tight closing of the lips and their eversion. With such injuries, ST swelling developed rapidly. In the case of injury to the lip, cheek, tip or wings of the nose and ear, defects of tissues of different sizes, shape and configuration are more likely to occur (Fig. 1).

At the objective examination it was not forgotten about the possibility of damage to the parotid gland and branches of the facial nerve, which can provoke a false idea of the nature and severity of injury, and in the mandibular area - the possible damage to the mandibular salivary gland and vessels. The features of the location and nature of the wounds around the eyes and the mouth during primary surgical treatment were taken into account to prevent the appearance of scar deformities, eyelid rotation and red lip edging.

According to the researchers, wounds after animal bites are mostly contaminated with the microflora that grows in their mouth, and presents microorganisms with pronounced pathogenic properties (aerobes (St.aureus, Str.viridans, gram-negative rods, etc.), anaerobes (Act. Fusobacterium spp., Prevotella spp., Porphyromonas spp.) And viruses, which can provoke infectious inflammatory process with their suppuration and the possibility of developing abscesses and phlegmon. Bitten wounds can be a gateway to the bacterium Capnocytophaga canimorsus, which can cause lightning sepsis or infection with tetanus. After a bite (or scratching) of cats, the development of felinosis («cat scratch disease»), caused by the Bartonella hensellae germ, and most often occurs as chronic regional lymphadenitis, is possible. It should also be borne in mind that animals, especially homeless and unvaccinated animals, are likely to be a source of rabies virus $[1,2,3,9,12]$.

The above stipulates the need for preventive measures against rabies and tetanus, which are organized, conducted and controlled at the state level in accordance with the normative documents (Order of the Ministry of Health of Ukraine of April 15, 2004 №205 «On Improvement of Measures for the Prevention of Rabies Diseases», MPH Order Ukraine dated 29.11.2007 No. 757 «On Amendments to the Order of the Ministry of Health of Ukraine dated 15.04.2004 
Table I. Distribution of bitten wounds of maxillofacial area by location

\begin{tabular}{ccccccc}
\hline \multicolumn{7}{c}{ Anatomical area } \\
\hline lips & cheeks & cheekbone & eyelids & nose & ear shells & multiple damage \\
\hline $35 \%$ & $29 \%$ & $8 \%$ & $2 \%$ & $5 \%$ & $1.8 \%$ & $19.2 \%$ \\
\hline
\end{tabular}

Table II. Distribution of patients with bite wounds of the maxillofacial area by age

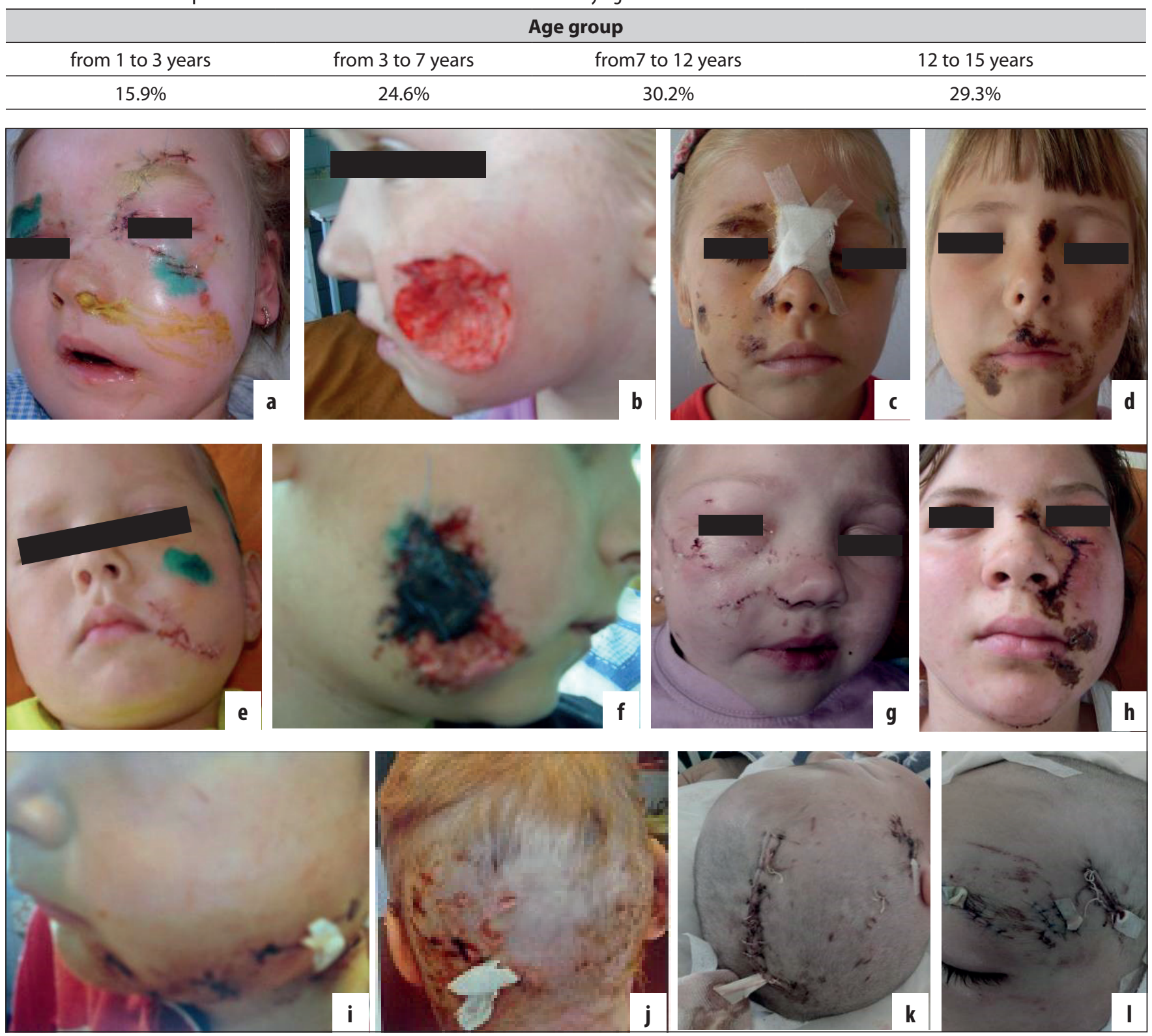

Fig. 1. The appearance of patients with bitten wounds of different anatomical localization on the head and neck at the stages of treatment

No. 205» On Improvement of Measures ... «, Annual Orders of the Ministry of Health of Ukraine «On Improvement of Prophylactic Vaccinations in Ukraine») [7, 8].

Paragraph 3 of the above Order clearly provides the first aid instruction to the injured person, according to which we thoroughly washed the wounds, scratches, saddles, covered areas with a stream of liquid soap, treated the edges of the wounds with $70^{\circ}$ alcohol or $5 \%$ tincture of iodine, imposed a sterile bandage. The edges of the wound were not healed within 3 days, except for the injuries that required special surgical interventions and according to vital indications: several guide stitches were applied after numerous pre-treatment wounds. To stop external bleeding, flashes of bleeding vessels were performed. A special registration form $\mathrm{N} \mathrm{058/o} \mathrm{is} \mathrm{completed} \mathrm{for} \mathrm{the} \mathrm{purpose} \mathrm{and} \mathrm{course} \mathrm{of}$ anti-rabies vaccinations.

To summarize, anti-rabbinic care consists of local wound treatment, administration of an anti-rabbit vaccine, or concomitant administration of anti-rabbit immunoglobulin and vaccine. Given that the rabies virus spreads perineu- 

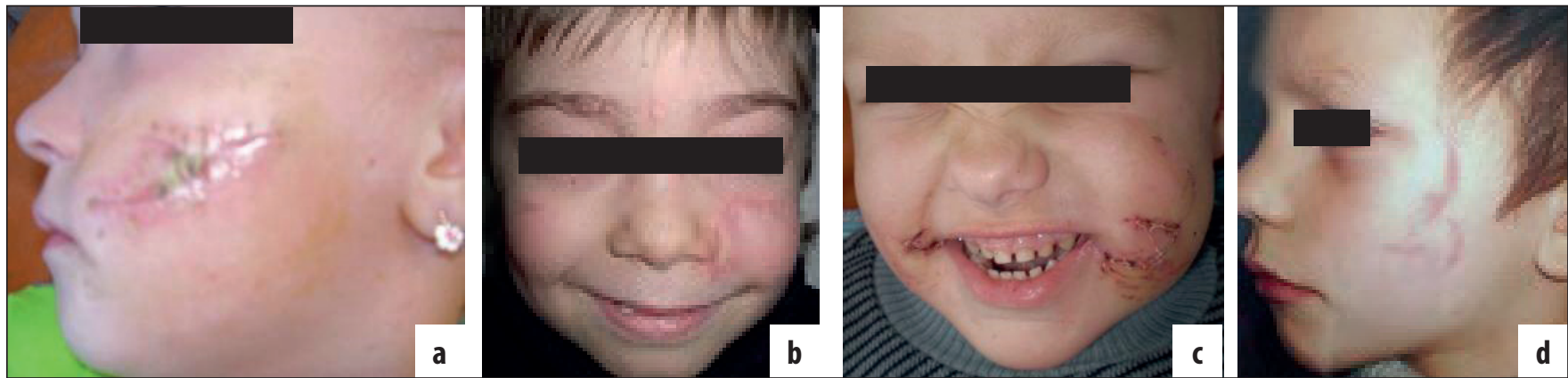

Fig. 2. General appearance of the face of children with scars formed after healing of bitten wounds

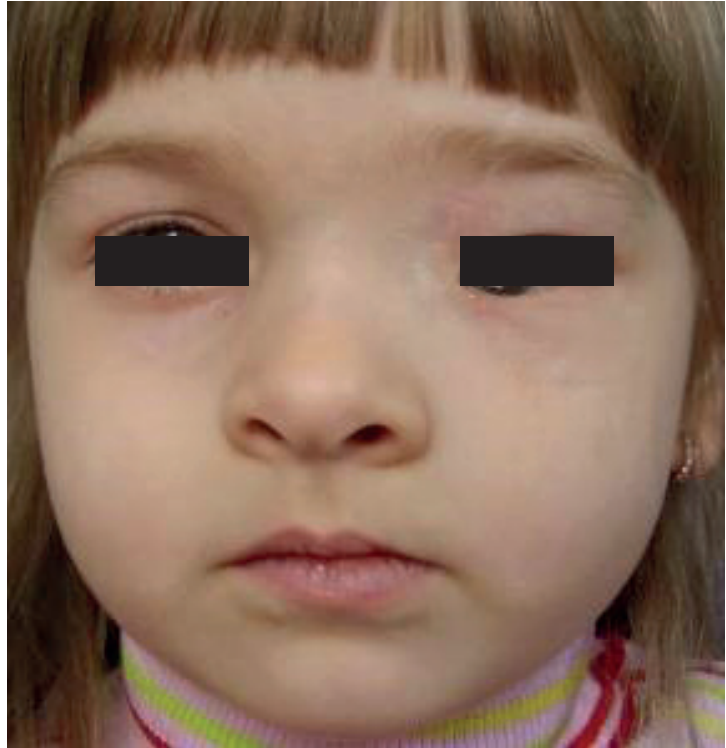

Fig. 3. The appearance of the face of the child $Y u, 3.5$ years, 1.5 years after the received bitten injuries. Cicatricial deformities of the eyelids of the left eye

rally at a rate of $3-5 \mathrm{~mm}$ per hour and bites inflicted in the MFA are located close enough to different departments of the CNS, and the choice of the wrong vaccination tactics can quickly lead to fatal consequences, we together with the radiologist have decided to determine indications for immediate anti-rabies vaccination, after which the children have been under our care for at least 30 minutes. After the course of immunotherapy, a certificate was issued indicating the type and series of drugs, the course of vaccinations, post-vaccination reactions. There is also a generally accepted general scheme of treatment-and-prophylactic vaccinations (regardless of the localization of the injury) [7].

In our observations, 80 children accompanied by relatives $(87.9 \%)$ went to the clinic for the first day after the trauma independently, 6 persons $(6.6 \%)$ were referred from trauma centers and 5 (5.5\%) were admitted through the clinic. at the place of residence. However, in 68 cases $(74.7 \%)$ the course of the bitten wounds was accompanied by the appearance of symptoms of acute inflammatory process of different severity. In 4 patients (4.4\%), there was a partial difference in sutures. We did not observe any other complications during the hospital stay.
The anamnesis collection revealed that relatives of only 21 patients (23.1\%) knew about the need for simple preventive measures for rabies that can be applied at home, and in these families, after the bite, carefully treated the wounds of $10 \%$ of the economic district. soap from the periphery to the center, preventing the spread of driftwood in the adjacent areas.

In 89 patients (97.8\%), immediately after hospitalization, we immediately began primary surgical treatment of wounds, and in 2 cases (2.2\%) they were quite insignificant in size and depth of lesions and they healed under the scab. Before surgery, questions were resolved on the type of anesthesia, the choice of suture, the immobilization of the operated area of the face and the subsequent nutrition of the child, taking into account the peculiarities of the anatomical location of the wounds.

The choice of method of anesthesia depended on the type and prevalence of the wound, its location and age of the child. In 51 cases $(56.0 \%)$ children were operated on with intravenous anesthesia, in $32-(35.2 \%)$ under infiltration anesthesia. In 8 traumatized $(8.8 \%)$ with extensive and deep wounds, surgical interventions were performed under intubation anesthesia. In local anesthesia, 25 children out of $32(78.1 \%)$ preferred infiltration anesthesia with a low concentration anesthetic solution, 5 - (15.6\%) performed conduction anesthesia, and $2-(6.3 \%)$ used a combination of them. In cases where surgical treatment was performed under general anesthesia, the indication for the choice of intubation anesthesia was the presence of wounds in the oral cavity or in cases where they penetrated into it.

It should be noted that the surgical treatment of the bitten wounds of the face and neck of each patient had certain difficulties, because they took into account the shape, location, nature and severity of the injury. To date, there are many unresolved issues regarding the features of surgical care in this category of patients, which are the basis for lively discussion in literature $[1,2,4,7,8,13]$.

In general, the suturing of penetrating wounds was layer-by-layer, starting with the oral mucosa with precise comparison of the direction of the muscle fibers, gentle excision of the non-viable areas and subsequent drainage for 2-3 days, except for shallow and small wounds. Sutures were applied to the skin, taking into account the Langer voltage lines. It should be noted that the most difficult to treat were bitten wounds in the area of the nose, eyelids and ears. 
In the case of bite or full tear off of the flap of the nose, cheeks or ears, the latter were repaired in 6 patients (6.6\%), having previously evaluated their viability and the timing of injuries. The postoperative period was necessarily accompanied by hypothermia of the replanted part of tissues for 1-2 days for 2-3 hours and carrying out of complex medication therapy.

According to the researchers, even when the signs of the inability of the tissues to full healing, their partial restoration is possible, because during the necrotization of the flap, the wound has time to fill with granulations, reducing the area of the defect. Replants that were previously housed in a clean plastic bag, had ice, and were sometimes stored for up to 24 hours were best used. The larger the implant by area, the shorter its storage life prior to implantation $[4,8]$, which coincided with the results we have accumulated.

In children with complicated course of the ST wound process and in the absence of treatment of fresh post-traumatic scars (Fig. 2), scar deformities are most often formed (13 patients $-14.3 \%$ ), which led to aesthetic and functional disorders of individual areas of the face and neck. They caused impaired growth of anatomical structures, led to the emergence of psycho-emotional disorders with impaired social adaptation of the child and very difficult to correct [10] (Fig. 3).

We did not observe keloid scars. In 12 patients (13.5\%) there were hypertrophic scars, while in the other 77 patients (86.5\%) where primary surgery was performed, they were visually evaluated as normotrophic.

To prevent coarse scarring in all cases, a set of measures was carried out, which included external ointment therapy after the removal of sutures elastoprotectors («Tsepan», "Warren», "Kontraktubeks») 3-4 g/d up to 6 months, pressing point massage on the scar through 7 days after suture removal, mimetic gymnastics (covers the muscles located in the projection of scars) 7 days after suture removal, physiotherapy (UFO at the time of sutures, electrophoresis with lidase and potassium iodide after suture removal). Considering the timing of scar formation [5], this complex, when necessary, was repeated 4-6 times a year by a course of 10-15 procedures, which in most cases allowed to obtain a good cosmetic result. For the same purpose, we have recently introduced into clinical practice an enzyme complex with collagenolytic proteases "Fermenkol", whose pharmacological action is aimed at the destruction of the components of the scar (collagen and hyaluronic acid). It has selective activity against the process of transformation of collagen, helps to reduce the thickness of the epidermis and dermis in areas of scar-altered skin. We apply "Fermenkol" in the form of applications (30-40 days, interval between courses 10-14 days), phonophoresis (10-12 procedures, interval between courses 10-14 days), electrophoresis (10-15 procedures, interval between courses 7- 10 days). This technique has already shown good immediate results, and considering that, the children who received such treatment are under the supervision of the dispensary, its effectiveness in the long term we will consider in the following publications. If it is necessary, surgical correction of hypertrophic scars is carried out, as indicated, no earlier than 1-2 years after injury.

\section{CONCLUSIONS}

1. In the structure of traumatic injuries of MFA in children who were hospitalized in the surgical department of PTCL of Poltava in the 8-year period, 5.3\% were patients with bitten wounds of the face and neck. Among the injured persons were predominantly children 7-12 years $(30.2 \%)$ with the highest proportion of wounds of the anatomical areas, which are prominent in relief. In $74.7 \%$ of cases, the bites were complicated by acute inflammatory processes.

2. 87.9\% of the victims approached the clinic with the assistance and support of their relatives, $6.6 \%$ were referred from trauma centers and 5.5\% were admitted through the polyclinic at the place of residence. The clinical picture and severity of bitten MFA wounds in children have individual features, which are largely due to topographic and anatomical localization of injuries.

3. Complex treatment of patients with bitten MFA wounds should be carried out according to the protocol of care for patients with bitten wounds, however, the choice of the optimal variant for primary surgical treatment of wounds and the amount of surgery should be determined individually depending on the severity of the injury, the duration of treatment compulsory consideration of the patient's vaccination. Particular attention should be paid to the normalization of the psycho-emotional state of patients and the prevention of scar formation.

\section{REFERENCES}

1. ZelenskiyV.A.,Mukhoramov F.S. Detskaya khirurgicheskaya stomatologiya i chelyustno-litsevaya khirurgiya [Pediatric surgical dentistry and oral and maxillofacial surgery]. Moscow: Medicine; 2008, 206 p. (Ru)

2. Topolnitskiy 0.Z. Stomatologiya detskogo vozrasta. Khirurgiya [Dentistry of childhood. Surgery]. Moscow: GEOTAR-Media; 2016, 311 p. (Ru)

3. Khar'kov L.V., Yakovenko L.M., Chekhova I.A. Khirurhichna stomatolohiya dytyachoho viku [Surgical dentistry of childhood]. Kyiv: Book Plus; 2003, 480 p. (UK)

4. Khar'kov L.V., Yakovenko L.N., Yefimenko V.P. ta in. Ukushennyye rany chelyustno-litsevoy oblasti u detey i ikh lecheniye [Bitten wounds of the maxillofacial region in children and their treatment]. Sovremennaya stomatologiya. 1998; 4: 40-46. (Ru)

5. Hurzhii 0.V., Bilokon' S.0., Krychevs'ka N.M. ta in. Chastota ta struktura ukushenykh ran miakykh tkanyn oblychchya ditey [Frequency and structure of bitten wounds of soft tissues of children's face]. Medichna gazeta Poltavshini. 2004 March 26. (UK).

6. Kutsevlyak V.I., Tkachenko L.V., Lyubyy V.V. ta in. Analiz povrezhdeniy, nanesennykh zhivotnymi, v Khar'kovskom regione [Analysis of damage caused by animals in the Kharkov region]. Voprosy eksperementalnoj $\mathrm{i}$ klinicheskoj stomatologii. 2003; 5: 23-25. (Ru)

7. Tkachenko P.I., Bilokon' S.0., Lokhmatova N.M. ta in. Ushkodzhennia shchelepno-lytsevoi dilianky u ditei [Damage to the maxillofacial area in children]: navchalnij posibnik. Poltava; 2019, 119 p. (UK)

8. Lyubyy V.V. Lecheniye detey s ukushennymi ranami chelyustno-litsevoy oblasti, nanesonnymi sobakami (kliniko-mikrobiologicheskoye issledovaniye) [Treatment of children with bitten wounds of the maxillofacial area inflicted by dogs (clinical and microbiological examination)]: dis ... cand. Med. nauk: Ukrainskaya Medicinskaya Stomatologicheskaya Akademiya. Poltava, 2004. 140 p. (Ru) 
9. Tkachenko P.I., Starchenko I.I., Bilokon S.0. et al. Insect bites as the cause of infectious and allergic inflammatory processes of the maxillofacial area in children. Wiad. Lek. 2019; 72 (5): 950-955.

10. Tkachenko P.I., Dobroskok V.0., Bilokon' S.0. ta in. Proiavy stresornoi reaktsii u ditey pry travmatychnomu poshkodzhenni shchelepnolytsevoi dilianky [Manifestations of stress response in children with traumatic damage to the maxillofacial area]. Aktualni problemi suchasnoyi medicini. 2017; 2: 274-279. (UK)

11. Kutsevlyak V.I., Lyubyy V.V. Rabochaya klassifikatsiya povrezhdeniy tkaney chelyustno-litsevoy oblasti, nanesennykh sobakami, u detey [Working classification of injuries of the tissues of the maxillofacial area caused by dogs in children]. Voprosy eksperementalnoj i klinicheskoj stomatologii. 2003; 6: 175-177. (Ru)

12. Tkachenko P.I., Starchenko I.I., Bilokon' S.0. ta in. Nespetsyfichni limfadenity shchelepno-lytsevoi dilianky u ditei (kliniko-morfolohichni aspekty [Non-specific lymphadenitis of the maxillofacial area in children (clinical and morphological aspects)]. Poltava, 2018. 120 p. (UK)

13. Strachunskiy LS, Bedenkov AV. Antibakterial'naya terapiya ukushennykh ran u detey [Antibacterial therapy for bitten wounds in children]. Detskij doktor. 2000; 4: 32-33. (Ru)
The presented work is a fragment of research paper of the Department of Pediatric Surgical Dentistry with propaedeutics of surgical dentistry, Ukrainian Medical Stomatological Academy "Integrative-differentiated substantiation of the choice of optimal methods of surgical interventions and volume of therapeutic measures in surgical pathology of maxillofacial area, state registration» № $0116 U 003821$.

\section{ORCID and contributorship:}

Pavlo I. Tkachenko - 0000-0001-5734-813 ${ }^{A, F}$

Serhii O. Bilokon - 0000-0002-7800-0516 ${ }^{B, E}$

Olha B. Dolenko - 0000-0002-7264-4206 ${ }^{\text {B,D }}$

Nataliia M. Korotych - 0000-0003-1893-2554 ${ }^{C, D}$

Natalia P. Bilokon - 0000-0002-5979-5528 C,D

Yuliia V. Popelo - 0000-0003-0002-366X ${ }^{B, D}$

\section{Conflict of interest:}

The Authors declare no conflict of interest.

\section{CORRESPONDING AUTHOR Nataliia M. Korotych \\ Ukrainian Medical Dental Academy \\ Shevchenko street 23, 36011 Poltava, Ukraine \\ tel: +380958820421 \\ e-mail:korotich.nat63@gmail.com}

Received: 28.02 .2020

Accepted: 08.05 .2020 